species whose death I attribute to collisions with trains are Mallard, Pintail, Blue-winged Teal, American Coot, Mourning Dove, Rock Dove, Blackbilled Cuckoo, Black-billed Magpie, Common Crow, Robin, Mountain Bluebird, Yellow - headed B l a c k b i r d, Meadowlark and Snow Bunting and several unidentified birds, including a large gull, a small owl and a warbler. A dead racing pigeon found near the highway over-pass at the west end of Chappell yards had a band belonging to an Edmonton pigeon club.

Some birds nest in the nooks and crannies of railway cars which are in storage or seldom used. Barn Swallows fly in and out of broken windows in old bunkcars and often nest on any suitable ledge or rafter. Rock Doves also choose similar sites. House Sparrows find many places in which to build their nests and Robins are partial to crossbeams and channel iron. Suddenly they are displaced by the sudden switching of these cars and often the nests are dislodged, resulting in damage to eggs and young. A few years ago at the diesel shop in the Chappell yard in Saskatoon a pair of kingbirds nested in the arch-bars of a set of trucks and as they had to be used, someone relocated the nest in a similar site about 20 feet away. The brood was raised successfully. In the summer of 1968 , while working at Humboldt, we stayed in a bunk car beside a caboose which had not been moved for some time. A pair of Robins had built their nest on a ledge above the caboose door and were busy feeding a youngster. One night both cars were moved about a quarter of a mile away and the young bird could be heard plaintively calling for its missing parents. Before we left in the morning I noticed an adult Robin perched on the roof looking down on the rest but we did not have time for further observations to establish whether this was the actual parent bird.

Another type of fatality I have noticed is "decapitation". Rock Doves commonly feed on grain from boxcars which have leaky doors and I have seen several birds' bodies with heads severed, owing to the unexpected switching of cars. I also saw this hap. pen to a Common Nighthawk, a species which sometimes roosts on the rails in daytime.

There is, however, a "credit" side to the railway location. In many places the railway right-of-way is the last vestige of prairie left in some intensely cultivated area. It is therefore natural habitat for many of our grass sparrows and sometimes the home of the Burrowing Owl. Killdeers choose railway ballast for nesting sites despite passing trains. In dry years railway ditches sometimes retain enough water for a brood of ducks. Rock Doves and Cliff Swallows are at home under trestle and masonry bridges, and hawks, owls and eagles use telegraph poles for perches in treeless areas. Many dams and reservoirs which supplied the water tanks of by-gone days still exist and are used by waterfowl. Thus the railway supplies some encouragement for bird life as well as sometimes causing its destruction.

\title{
MILK RIVER VALLEY, ALBERTA, BRIEF EXPLORATIONS
}

\section{by Wayne W. Smith, 8220 Elbow Drive, Calgary 9, Alberta}

During the summer of 1971 I was employed in the Cypress Hills Provincial Park of Alberta. Since the Milk River is only about 60 miles away, I made five day-long excursions to the Milk River Valley south of Onefour and Manyberries, Alberta.
Some people are impressed by mountains. The Milk River Valley has much the same impressive aspect, being in effect an inverse mountain range. To me the Milk River Valley was close to a wilderness, though cattle grazing the area are damaging the land; human 
signs are few, being limited to scattered habitations, occasional fences and a few power lines. Still, the area is uniquely rugged and has an unusual flora and fauna. Several plant species, for example, yucca, are found nowhere else in Canada. I was enthralled by the area and believe it has great potential as a near-wilderness preserve. Perhaps my brief observations will encourage other naturalists to visit this site to appreciate better its values.

May 30 - Horned Larks, McCown's Longspurs and Chestnut-collared Longspurs were common along the way. Other species of interest were Longbilled Curlews, Upland Plovers and Lark Buntings. Because water was scarce, there were few ducks. Near the Cressday water reservoir, about 40 miles south of Elkwater, there were the usual prairie ducks, several Swainson's and Ferruginous hawks (one dark phase of each), one Prairie Falcon and several Marsh Hawks.

When one approaches a mountain range, the peaks are usually visible from afar and gradually loom larger on the horizon. The Milk River Valley was practically beneath our feet before we saw it, and instead of craning upwards we stood and stared down past our feet. As we approached the edge of the valley, we saw a female Pronghorn being stalked by some animal that we frightened away. I raced to the edge of the valley in time to see a Bobcat about 50 feet below. We stared at each other until my companion's voice sent it running off. In a matter of seconds it covered several hundred yards across a rocky draw. I was surprised to see that it was bright rusty-red, more so than pictured in field guides.

In the rocky coulees along the edge of the valley there were many prickly pear and pincushion cacti and other arid-land plants, notably greasewood, rabbit brush and bitterroot. Primroses were blooming and yuccas were present though scarce.

We found two Mule Deer resting in a grassy hollow and sighted one or two Yellow-bellied Marmots among a pile of boulders. Rock Wrens were within hearing at all times. These birds are supposed to have buffy tail corners, but those we saw all had complete buffy tail bands. Two abandoned Ferruginous Hawk eyries caught our attention and later we saw a Sage Grouse.

June 17--On this day the prairie adjacent to the Valley held many flowers. Within the Valley scarlet mallow was especially prominent. Besides the usual bird species I saw an unidentified falcon. It appeared to be a small Peregrine with a white breast and dark belly.

July 3-The first highlight was a small Prairie Rattlesnake crossing a gravel road north of the Valley. This was the first I had seen in Alberta. Upon climbing down the edge of the Valley I discovered at least four pairs of Lark Sparrows in one small area and flushed two Golden Eagles from an eyrie par't way up the cliff.

On the flats on both sides of the Milk River sagebrush plants were small, but closer to the river they were taller and closer together. Along the edges of some poplar groves the sage was dense and over 12 feet high, due, no doubt, to increased moisture.

In the wooded areas four warblers were prevalent: Yellow Warbler, Yellowthroat, MacGillivray's Warbler and Yellow-kreasted Chat. Here also were numerous Rufous-sided Towhees. The only woodpeckers were two flickers, one a Red-shafted Flicker. At the Valley edge I found a Nighthawk nest with two eggs.

In a scree or talus slide I searched for and found a scorpion, a rare invertebrate animal in these parts. I scooped it into an emptly film case and kept it alive for a week.

July 5-Near where I had seen a rattlesnake on July 5 I saw another that measured three feet, seven inches in length.

At the Valley, Western Meadowlarks, Reck Wrens and Lark Sparrows provided a musical background while a Golden Eagle soared over the opposite side. After some time I noticed two swallows feeding in the air on the same level as myself. They appeared to be feeding young back in a crevice in 
the cliff. After a careful inspection I identified these as Violet-green Swallows, a species normally found breeding several hundred miles westward in the mountains.

[Ed. Note: For a nesting record in the Saskatchewan Cypress Hills see Blue Jay 27:144-145, 1969.]

Two Mule Deer were seen on the way to the river and besides the passerines noted on July 3 Black-capped Chickadees and Mountain Bluebirds were noted. I swam across the river and found at least six Bullock's Orioles in a grove of trees. Because I had left my binoculars on the other side, I had to get close to identify them, but they proved to be fearless and I was able to approach to within several feet of them.

On the steep slopes of the Valley I heard a cascading song that I recognized at once as a Canyon Wren, a bird I had heard in the Okanagan Valley in British Columbia in the spring. The tumbling melody of notes that make up its song could easily be distinguished from the Rock Wrens and nearby Sprague's Pipits. I searched for the songster for some hours but without success. I was disappointed not to actually see it, but was still elated to have identified it. The only previous occurrence of the Canyon Wren in Canada was in the Osoyoos Arid Biotic region of the southern Okanagan Valley.

A few miles north of the Valley I saw a pair of shorebirds that I believe were Mountain Plovers. I am not certain, however, for when I stopped to check they flew off across the prairie. This species has been previously recorded by Dr. J. Dewey Soper at Wildhorse, about 25 miles away (four on June 22, 1941), and by Cleve R. Wershler at Elkwater, about 45 miles away (two on June 12, 1966). (Dr. Soper also reported one near Bracken, Saskatchewan on June 5, 1939).

August 28 - There were a hundred ducks gathered on the Milk River, apparently massing for migration. Three species not previously seen in the area were: Sparrow Hawk, Tree Swallow and Robin. At the river I found a Brown Thrasher bathing along with several Rufous-sided Towhees.

\section{WHITE-TAILED DEER IN NORTHERN SASKATCHEWAN}

\section{by $\mathbf{E}$. Otto Höhn, University of Alberta, Edmonton, Alberta}

White-tailed deer are reported by Beck (1958) as occurring in southern and central Saskatchewan, with Prince Albert National Park as the most northern locality named in connection with its distribution in the province. The publication cited gives a similar northern boundary for the Saskatchewan range of the mule deer, but in a later publication, the author (Beck, 1964) records the identification of deer tracks at two points on the south shore of Lake Athabasca, near Beaver Point, July 1960, and near William Point, July 1961. No deer were seen, but the tracks were attributed to mule deer as the most likely species in the area.

On July 26, 1971, I found two very clear deer tracks on the sandy shore of Lake Athabasca, a few miles west of the Alberta/Saskatchewan border. In view of the distribution maps of the white-tailed and mule deer in Hall and Kelson (1959) and those prepared for their range in Alberta by $R$. Webb in 1959 and reproduced in Soper's "Mammals of Alberta" (1964), I would also have interpreted these tracks as probably those of mule deer.

However, when $I$ was at Uranium City a few days later, a taxi driver told me about two "jumping deer" (in my experience, a vernacular name for the white-tailed deer) he had seen crossing a road near the town earlier that month. Later Mr. J. A. Macauley, Conservation Officer at Uranium City wrote to me that on July 20, 1971, he saw two white-tailed deer beside the road at Ace Lake, five miles east of 